\title{
Students' attitude to and motivation for outdoor life
}

\author{
Authors' Contribution: Inga Liepina ACDEFG, Daina Krauksta ABFG
A-Study Design \\ B - Data Collection \\ C - Statistical Analysis \\ D - Data Interpretation \\ E - Manuscript Preparation \\ $F$ - Literature Search \\ $\mathrm{G}$ - Funds Collection \\ Latvian Academy of Sport Education, Riga, Latvia
}

Key words: outdoor education, outdoor life experience, motivation, attitude

\begin{tabular}{c|l}
\hline Background: & $\begin{array}{l}\text { Abstract } \\
\text { Material/Methods: }\end{array}$ \\
Results: & $\begin{array}{l}\text { The aim of the research was to find out how the process of the study course Tourism } \\
\text { at the Latvian Academy of Sport Education affects the formation of the students' atti- } \\
\text { tude towards outdoor life education. }\end{array}$ \\
In order to find it out, first of all, we clarified the students' previous knowledge, under- \\
standing of outdoor education, as well as their previous outdoor life experience. The \\
total number of participants was 97 students. Both theoretical and practical classes, \\
as well as a five-day outdoor camp with various outdoor activities were included in the \\
study course Tourism. The method of inquiry was used in the research.
\end{tabular}

Word count: 2,788

Tables: 3

Figures: 3

Received: November 2013

References: 23

Corresponding author:

Inga Liepina

Latvian Academy of Sport Education

333 BrivibasGatve, Riga, LV 1006, Latvia

Phone: +371 67799543, mob.: +371 26525949

E-mail: Inga.Liepina@Ispa.lv 


\section{Introduction}

Students' attitude and motivation is the key to successful and professional acquisition of education [1]. Motivation process is based on the whole human activity and its interaction with external factors that determine human behavior. These motives are rooted in our needs, experiences, perception, and this subjectively expresses in our emotions, desires, aspirations, interests and ideals. Motivation moves us forward, guides our actions and sustains our behavior in the long term [2].

In recent years scientific research regarding students' motivation has focused more on the socio-cognitive approach, namely, on students' inner motivation which helps to achieve academic goals - purposefulness, importance, confidence and external motivation - recognition, competition between students, performance monitoring and assessment [1, 2, 3, 4]. Minor unexpected cognitive tension has motivational qualities [2].

Grounding on the cognition theory, we can say that learning is an active process, and research shows that students' motivation on problem-based education [5, 6] and on experience-based learning [7] is significantly increasing. Also a number of researchers emphasize that the learning process which is based on outdoor living experience, i.e. learning by doing, not only provides specific knowledge in outdoor living conditions, but also develops problem-solving skills, collaboration skills and positive attitude towards each other, and, of course, one of the most important skills in real life, i.e. environmental skills [8, 9, 10, 11, 12, 13, 14].

Experiential learning focuses on each individual's experience in common teaching process, when each member receives his/her own necessary and important insights, which can be used personally, and each participant can express and realize oneself on the basis of previously acquired knowledge.

Outdoor life skills are essential to a comprehensively developed part of personality [15], because they provide the highest experience and challenge, most correct awareness of each other and the surrounding world.

In our research the strategic significance of an outdoor camp is that it envisages the learning and development of not only knowledge and skills of a specific Tourism study course, the increase of one's individual professional competence, but also combines both outdoor life skills (social life skills) and the development of interpersonal relations, physical abilities, and positive motivation [16, 17].

Our observations show that tourism studies radically manifest students' individual and group/team interests and also operational activity in order to acquire knowledge and skills exactly in an outside study process rather than in the academic environment.

Outdoor tourism study, in contrast to academic study, is a way of positive mutual establishment of relationships and development of students' personal experience. Outdoor tourism studies are related to a constructive approach: analysis and evaluation of the situation, construction of task formulation activities and realization based on their experience and also adaptability depending on individual circumstances. Outdoor tourism studies are focused on students' autonomy in a learning process and they can be applied to self-directed learning [18, 19].

Students' attitude towards learning usually determines the extent to which students adopt and implement educational requirements. Attitude towards the learning process reflects students' behavior and qualities but does not reveal driving forces of the behavior and study process [20]. Attitude generally can be defined as a relatively stable and self-dependent, positively or negatively evaluative reaction, directed to specific people, objects or ideas that influence or motivate their associated behavior [21].

In our view, the driving force behind the study is the informal side, i.e. outdoor tourism education in which practical activities are carried out and show students' actual attitude, motivation and the course acquisition level.

The aim of the research was to determine how the process of the study course program Tourism at the Latvian Academy of Sport Education (LASE) affects the formation of the students' attitude towards outdoor life education. 


\section{Material and methods}

97 of LASE full-time professional Bachelor study program "Sports Science" 2nd year students who in four study years will acquire two of the selected qualifications - Recreation Specialist, Physical Education teacher, Sports Manager and Sports Coach participated in this research (61 males and 36 females). The study course Tourism (3 ECTS) included both theoretical (4) and practical classes, as well as participation in a 5-day outdoor camp with various outdoor activities hiking, tourism control combined hiking, team tourism obstacle course (rope), orienteering, etc. During the research (from March to July, 2013) the inquiry method was used 6 times.

The research was administered by LASE Inner Quality Center to evaluate the study course Tourism outcomes. Quantitative research method was applied in the research. Students participated in the inquiry and filled out the questionnaires. The questionnaire was adapted in the study of 2012 "Outdoor Education and Outdoor Life Experience of Students of the Latvian Academy of Sport Education (LASE)" [22].

In order to accomplish the objective, firstly we found out students' prior knowledge, understanding of outdoor education and previous outdoor life experience. There were also questionnaires on the study course Tourism in order to get the first impressions of the particular outdoor activity, as well as 3 days after the completion of the course program to determine our main goal - how the study process affects students' attitude towards outdoor education.

To evaluate students' previous and outdoor life experience obtained during a country camp a questionnaire was used including 15 questions which were assessed at 5 levels (level 1 was the lowest, level 5 was the highest). The questions were about living in outdoor conditions, nature factors and terrain orienteering, nature protection, mutual cooperation, leadership, individual understanding and view of outdoor life.

\section{Results}

The study course Tourism started with theoretical lectures, where students were introduced with the study course content, assessment, and an introductory lecture on outdoor education, including types of hiking, individual and group equipment, food, tourism camps, etc. Students were also asked to write about how much of new information (\%) they have learned from the theoretical lectures. None of the students knew all the information told by the lecturer before, also $17 \%$ of the students showed that from theoretical lectures they had acquired $20-40 \%$ of the new information, while $26 \%$ of students acquired $50-70 \%$ of the new information. $40 \%$ of students gained even $80-$ $100 \%$ of the new information. Hence it can be concluded that students have little theoretical preliminary knowledge on outdoor education.

Since students' attitude and motivation is fundamental to a successful and professional education [8], we found out how motivated students were to practically learn things that were spoken of in the lecture with the help of questionnaires. It was found that initially more than a half (67\% women and $60 \%$ men) believed that the offered outdoor educational knowledge could be useful in the chosen profession and also individually participating in different outdoor activities. Despite the fact that all offered professional qualifications are more or less related to outdoor education, $17 \%$ women and $18 \%$ men doubt that it will ever be needed; therefore, the motivation to learn will be lower than in those who initially had a positive attitude. We assume that the students' motivation towards active cognition process will decrease, perhaps due the lack of experience, interest and wish "to step out of" the habitual everyday comfort.

It is observed that female students have slightly higher motivation and outdoor life experience than male students (Figure 1,2).

In the next question we also verified the students' little outdoor living experience. Despite the fact that Latvian natural resources are favorable to diverse outdoor activities, except mountain hiking, student experience inquiry on various outdoor activities showed that a high number of students had never attended any of them.

As shown in Figure 2, from among all the respondents, only $32 \%$ of women and $37 \%$ of men had at least once participated in a boat trip, none of the male respondents had ever participated in 
ski hiking, and very few respondents had participated in at least one-day cycling tour. Only $35 \%$ of women and $27 \%$ of men had participated in a two-day hike at least once in a lifetime.

Outdoor activities require specialized gear. The respondents were questioned whether they had the necessary outdoor activity equipment. Of course, by evaluating the above issues, the results were not surprising, because, if there had been so little activity in various outdoor activities, only few had their own personal equipment.

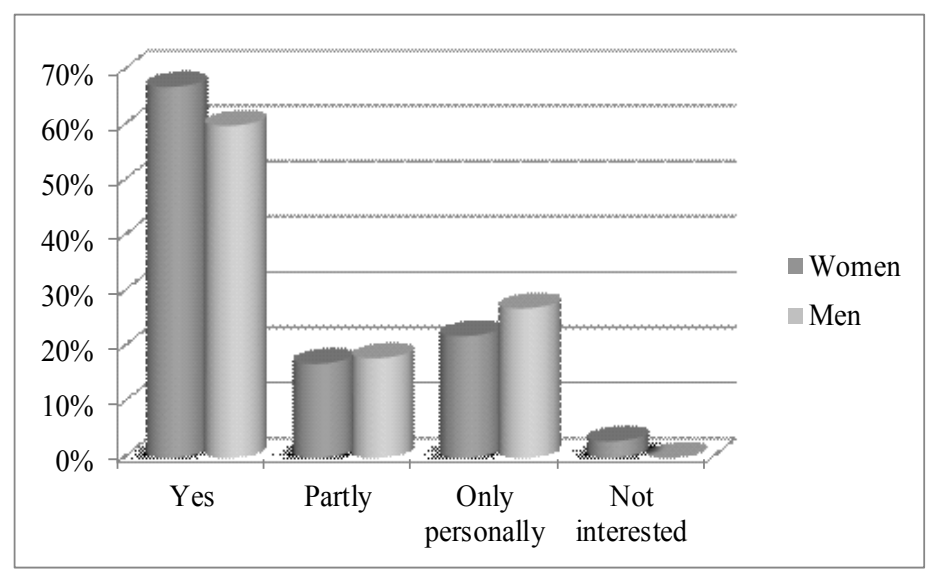

Fig. 1. Students' motivation to learn the acquired information from theoretical lectures in practice

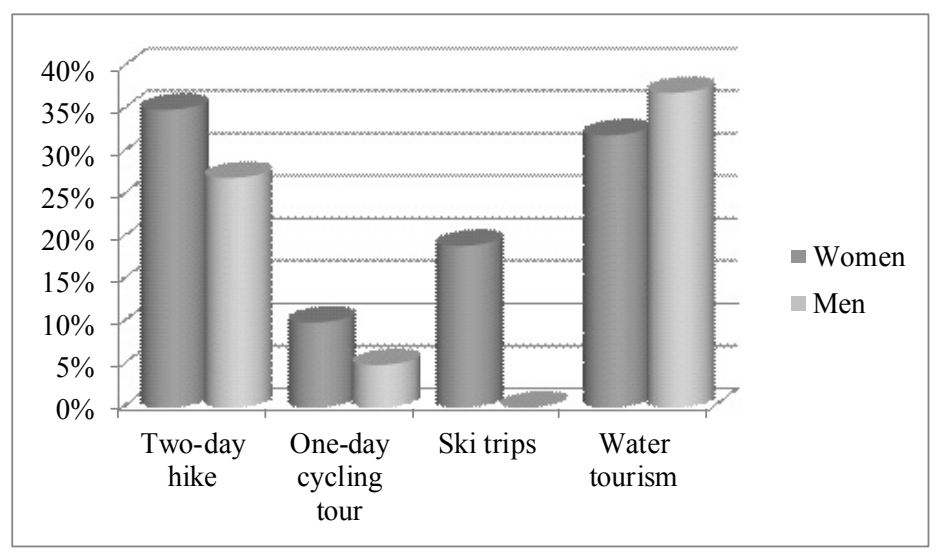

Fig. 2. Students' prior experience in various outdoor activities

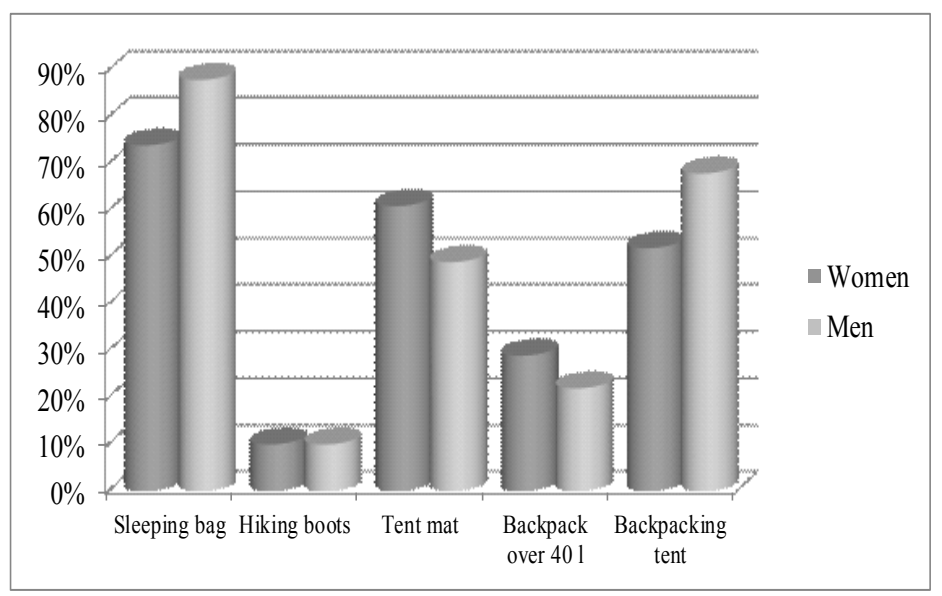

Fig. 3.Students' personal equipment before the study course program Tourism 
One of the most important pieces of hiking equipment is a decent pair of boots. A hiking backpack is essential only to $22 \%-29 \%$ of students. The graph shows that relatively many have sleeping bags and tents (Figure 3 ).We found out that $85 \%$ of respondents had stayed in tents outside their residence. However, the quality of sleeping bags must also be taken into account. Many have sleeping bags from their parents who have served for more than 10 years, many have tents and sleeping bags purchased in supermarkets, which are not of the best quality.

It was found that $5 \%$ of the respondents for a short time period had worked in guide and scout organizations, $21 \%$ - in young guards' organizations and $11 \%$ had participated in other outdoor life programs. $73 \%$ of men and $55 \%$ of women had participated in outdoor condition camps. However, the study did not analyze the content of the camps (offered activities).

$84 \%$ of men and $82 \%$ of women stated in the questionnaires that they had the wish to test themselves under extreme conditions and challenge themselves in outdoor life conditions. A large part of students within the framework of the study course Tourism organized a camp and it was a great challenge. All camp participants lived in tents, cooked their own pre-planned meals on the camp fire and, of course, participated in all camp activities - hiking (18 miles) tourism control combined hike (8 miles), team tourism obstacle course (rope), orienteering competitions and aquatic tourism (24 miles).

Before the camp we found out students' self-assessment regarding their skills and skills prior to study course program Tourism (Table 1).Students had to rate their skills in 1-5 point scale of values, where 1 was "very low" and 5 was "very high".

In the same way we determined students' self-assessment of their abilities, skills and growth of the knowledge regarding outdoor living experience after the tourism camp event (Table 2).

Participant assessment for outdoor life experience overall in all parameters (Table 3 ) suggests that the study process for the majority of students have contributed to mastering of outdoor living experience. After the study program Tourism students' performance improved in almost all parameters and the percentage of marks rose to 4 and 5 point scale of values.

When analyzing individual criteria, the highest growth of students' self-assessment received "personal choice of equipment for outdoor life", "overcoming the natural obstacles (rivers, steep slopes, etc.)", "orientation in the area" and "ability to share and live with others". In contrast, relatively low - close to the levels which were prior the study course program Tourism - growth was observed in the criteria "personal hygiene" and "understanding of the nature conservancy and conservancy of objects".

Table 1. Students' $(n=88)$ self-assessment of their skills and skills prior to the study course program Tourism

\begin{tabular}{|c|c|c|c|c|c|c|}
\hline \multirow{2}{*}{ No. } & \multirow{2}{*}{ Criteria } & \multicolumn{5}{|c|}{ Value scale } \\
\hline & & 1 & 2 & 3 & 4 & 5 \\
\hline 1. & Living in the tents for more than 2 days & 8 & 11 & 19 & 21 & 29 \\
\hline 2. & Personal equipment selection for outdoor life & 6 & 20 & 24 & 28 & 10 \\
\hline 3. & Personal and group household equipment selection & 8 & 20 & 35 & 19 & 6 \\
\hline 4. & Product selection & 5 & 12 & 35 & 25 & 11 \\
\hline 5. & Making camp fires & 5 & 15 & 24 & 27 & 17 \\
\hline 6. & Warm meal (soups, second course) cooking outdoors & 15 & 23 & 30 & 15 & 5 \\
\hline 7. & Crossing of natural barriers (rivers, steep slopes, etc.) & 7 & 19 & 13 & 35 & 14 \\
\hline 8. & $\begin{array}{l}\text { Orientation in the area (using a sports map, cardinal points, } \\
\text { scale stating without a compass) }\end{array}$ & 11 & 23 & 33 & 15 & 6 \\
\hline 9. & Overcoming of unfavorable natural conditions (rain, wind) & 3 & 10 & 28 & 33 & 14 \\
\hline 10. & Personal hygiene & 0 & 3 & 14 & 36 & 35 \\
\hline 11. & Ability to share and live with others & 0 & 2 & 25 & 26 & 35 \\
\hline 12. & Leadership skills in various situations and in the team & 3 & 12 & 34 & 25 & 14 \\
\hline 13. & Understanding of the nature conservancy and conservancy of objects & 1 & 10 & 20 & 33 & 24 \\
\hline 14. & Understanding of outdoor life in general & 2 & 6 & 23 & 39 & 18 \\
\hline \multirow[t]{2}{*}{15} & $\begin{array}{l}\text { Communication capacity building, ability to cooperate, work as a team } \\
\text { in camp conditions and also competition }\end{array}$ & 0 & 3 & 14 & 33 & 38 \\
\hline & Total: & 74 & 189 & 371 & 410 & 276 \\
\hline
\end{tabular}


Table 2. Students' $(n=88)$ self-assessment of their skills and skills after to the study course program Tourism

\begin{tabular}{|c|c|c|c|c|c|c|}
\hline \multirow{2}{*}{ No. } & \multirow{2}{*}{ Criteria } & \multicolumn{5}{|c|}{ Value scale } \\
\hline & & 1 & 2 & 3 & 4 & 5 \\
\hline 1. & Living in the tents for more than 2 days & 1 & 8 & 21 & 31 & 27 \\
\hline 2. & Personal equipment selection for outdoor life & 0 & 9 & 25 & 35 & 19 \\
\hline 3. & Personal and group household equipment selection & 1 & 8 & 23 & 42 & 14 \\
\hline 4. & Product selection & 0 & 13 & 31 & 28 & 16 \\
\hline 5. & Making camp fires & 0 & 10 & 18 & 35 & 25 \\
\hline 6. & Warm meal (soups, second course) cooking outdoors & 5 & 10 & 23 & 29 & 21 \\
\hline 7. & Crossing of natural barriers (rivers, steep slopes, etc.) & 0 & 1 & 17 & 37 & 33 \\
\hline 8. & Orientation in the area & 1 & 5 & 24 & 37 & 21 \\
\hline 9. & Overcoming of unfavorable natural conditions (rain, wind) & 1 & 2 & 21 & 35 & 29 \\
\hline 10. & Personal hygiene & 0 & 3 & 13 & 34 & 38 \\
\hline 11. & Ability to share and to live with others & 0 & 0 & 12 & 34 & 42 \\
\hline 12. & Leadership skills in various situations and in the team & 2 & 3 & 25 & 37 & 21 \\
\hline 13. & Understanding of the nature conservancy and conservancy of objects & 1 & 3 & 17 & 39 & 28 \\
\hline 14. & Understanding of the outdoor life in general & 0 & 2 & 13 & 38 & 35 \\
\hline \multirow[t]{2}{*}{15} & $\begin{array}{l}\text { Communication capacity building, ability to cooperate, work as a team } \\
\text { in camp conditions and also competition }\end{array}$ & 0 & 2 & 10 & 39 & 37 \\
\hline & Total: & 12 & 79 & 293 & 530 & 406 \\
\hline
\end{tabular}

Table 3. Students' $(n=88)$ self-assessment

\begin{tabular}{|l|c|c|c|c|c|}
\hline & \multicolumn{5}{|c|}{ Value scale } \\
\cline { 2 - 6 } & $\mathbf{1}$ & $\mathbf{2}$ & $\mathbf{3}$ & $\mathbf{4}$ & $\mathbf{5}$ \\
\hline $\begin{array}{l}\text { Students' self-assessment of their abilities, skills and growth of the } \\
\text { knowledge regarding outdoor life experience after the tourism camp }\end{array}$ & 12 & 79 & 293 & 530 & 406 \\
\hline $\begin{array}{l}\text { Students' ( } \mathrm{n}=\text { 88) self-assessment of their skills, skills prior to the } \\
\text { study course program Tourism }\end{array}$ & 74 & 189 & 371 & 410 & 276 \\
\hline Decrease or increase & $\mathbf{- 6 2}$ & $\mathbf{- 1 1 0}$ & $\mathbf{- 3 9}$ & $\mathbf{+ 1 2 0}$ & $\mathbf{+ 1 3 0}$ \\
\hline
\end{tabular}

\section{Discussion}

The research shows that LASE students' outdoor living experience compared to experiences of other country students, such as Norway, the Czech Republic, or Sweden, is very small. The study was not looking at the factors that affected students' outdoor life experience before starting the university. We believe that the major factors may be traditions in the family, at school, and also the economic situation of each student as an individual and the country in general.

The study course program Tourism includes a significant development of knowledge and skills in real outdoor conditions with the specific objective - the ability to use the acquired knowledge and skills in their future professional activities, which is important for the future recreation specialists, physical education teachers, sports managers and sports coaches. This learning process is related to students' physical, emotional and spiritual experience, because it is characterized by unusual physical activity and the process itself from the outset is quite emotional, full with uncertainty, anxiety, even fear and emotional experiences of all the team members.

By the end of the course, students admitted that the experience they gained was very useful and necessary. It increased the students' motivation to continue to participate or organize their own variety of outdoor activities, as well as planning to buy new equipment for outdoor life. It must be noted that the survey took place shortly after the end of the study course. The study demonstrated only short-term motivation. However, to ensure long-term motivation, further studies are required.

\section{Conclusions}

Students of LASE have very small previous outdoor living experience in such activities as hiking, biking tours, boat trips, skiing trips. 
Most of the students do not have proper equipment for outdoor activities, for example, suitable hiking boots, backpacks and other necessary outdoor equipment.

The study course program Tourism increased students' outdoor living experience. 39\% of students found the acquired outdoor experience to be very useful, $53 \%$ necessary and only $3 \%$ of students found the information to be unnecessary. $47 \%$ of the students bought equipment for active tourism in order to continue to participate in various outdoor activities. Thus it can be concluded that the course comprised a positive attitude and at least a temporary motivation for further formation of an outdoor experience.

We think that outdoor camp organization should be recommended in higher education process both for learning of knowledge and skills, and for the development of professional competences, as well as for the facilitation of outdoor skills, development of mutual relations and positive motivation.

\section{References}

1. Howey SC. Factors in Student Motivation. Retrieved from the NACADA Clearing house of Academic Resources, 2008. [on-line at http://www.nacada.ksu.edu//Clearinghouse/Advising Issues/Motivation.htm] [accessed July 2013]

2. Geids NL, Berliners DC. Pedagogiska psihologija [Education Psychology]. Riga: Zvaigzne ABC; 1999. Latvian.

3. Goh E. The Value and Benefits of Field trips in Tourism and Hospitality. Education Higher Learning Research Communications. 2011;1(1):60-70.

4. Lice M. Correlation between motivated learning and successfulness in life activities. In: Theory for Practice in the Education of Contemporary Society 5th International Scientific Conference Riga; 2010, 183-188.

5. Rotgans J. Problem-based learning and students motivation: The role of interest in learning and achievement. In: O'Grady G, ed. PBL and problematization of teaching and learning, 2012; 3, 298.

6. Tsankov NS. Students' motivation in the process of problem based education in chemistry and environmental sciences. International Journal of Humanities and Social Science. 2012;2(21):167-171.

7. Beard C. Transforming the student learning experience: a pedagogic model for everyday practice hospitality, Leisure, Sport and Tourism Network, 2009.

[on-line at http://www.heacademy.ac.uk/assets/documents/subjects/hlst/e3_transform_the_sle.pd] [accessed May 2014]

8. Adkins C, Simmons B. Outdoor, experiential, \& environmental education: Converging or diverging approaches? ERIC Digest, EDO-RC-02-1. 2002.

9. Fagerstam E. Space and Place. Perspectives of outdoor teaching and learning. Linkoping Studies in Behavioural Science 2012; 167.

10. Henderson K. Got research in experiential education? Theory and evidence. Journal of Experiential Education 2004;26(3):184-189.

11. Higgins P, Nicol R, Eds. Outdoor education: Authentic learning in the context of landscapes. Kinda Kunskaps Centrum, Sweden 2002; 2:93.

12. Liedtke G, Lagerstr-m D. Outdoor education or education outdoors - educational concepts toward sanactive life style? Proceedings from the international symposium. Outdoor Sports Education. Hruba Skala, Czech Republic 2004: 67-71.

13. Turcova I, Bartunek D, Martin A. Outdoor sports in educational and recreational programmes. In: Proceedings from 3nd International Mountain and Outdoor Sports Conference, Hruba Skala, Czech Republic. Praha: IYNF; 2007.

14. Turcova I, Neuman J, Martin AJ. Navigating the outdoor education terminological jungle: Outdoor education in the Czech Republic. Pathways: The Ontario Journal of Outdoor Education 2004; 16(2): 25-27.

15. Mirrahimi S, Tawil NM, Abdullah NAG, Surat M, Usman IMS. Procedia engineering. Developing conducive sustainable outdoor learning: the impact of natural environment on learning. Social and Emotional Intelligence. 2011;20:389-396.

16. Christie B, Higgins P. Residential outdoor learning experiences and Scotland's school curriculum: an empirical and philosophical consideration of progress, connection and relevance. Scottish Educational Review. 2012;44(2):45-59.

17. House of Commons Education and Skills Committee, Education Outside the Classroom: Second Report of Session, 2004.

[on-line at http://www.docs.hss.ed.ac.uk/education/outdoored/education_outside_classroom.pdf] [accessed May 2014]

18. Hill AP. Motivation and university experience in first-year university students: A self-determination theory perspective. Journal of Hospitality, Leisure, Sport \& Tourism Education, 2012. 
19. Thanasoulas D. What is learner autonomy and how can it be fostered? The Internet TESL Journal, 2000. [on-line at http://iteslj.org/Articles/Thanasoulas-Autonomy.html] [accessed July 2013].

20. Skidmoer RL. Proximal factors predicting student performance in a self-paced college psychology course (Occasional Research Paper, No. 7). Morehead, KY: Morehead State University, Center for Educational Research and Leadership; 2003.

21. Olson JM, Zanna MP. Attitudes and attitude change. Annual Review of Psychology. 1993;44:117-154.

22. Liepina I, Krauksta D. Outdoor Education and Outdoor Life Experience of the Latvian Academy of Sport Education. LASE Journal of Sport Science. 2013;44(2):4-13. 